\title{
Study on Determining Factors of Employee Retention
}

\author{
Bodjrenou Kossivi' ${ }^{1}$ Ming Xu1 , Bomboma Kalgora ${ }^{2}$ \\ ${ }^{1}$ Glorious Sun School of Business and Management, Donghua University, Shanghai, China \\ ${ }^{2}$ School of Economics and Management, Shanghai Maritime University, Shanghai, China \\ Email: kossbodj@gmail.com,xuming@dhu.edu.cn, research.kb@outlook.com
}

Received 24 March 2016; accepted 27 May 2016; published 30 May 2016

Copyright (C) 2016 by authors and Scientific Research Publishing Inc.

This work is licensed under the Creative Commons Attribution International License (CC BY).

http://creativecommons.org/licenses/by/4.0/

cC) (i) Open Access

\begin{abstract}
Employees are the most valuable assets of an organization. Their significance to organizations calls for not only the need to attract the best talents but also the necessity to retain them for a long term. This paper focuses on reviewing the findings of previous studies conducted by various researchers with the aim to identify determinants factors of employee retention. This research closely looked at the following broad factors: development opportunities, compensation, work-life balance, management/leadership, work environment, social support, autonomy, training and development. The study reached the conclusion that further investigations need to be conducted regarding employee retention to better comprehend this complex field of human resource management.
\end{abstract}

\section{Keywords}

Human Resource, Employee Retention, Determining Factors

\section{Introduction}

Employees have been important resources to any organization. Based on their critical character, they can be termed the life-blood of an organization. Advancement in technology has caused most organizations to be more and more technology driven. However, this situation does not reduce the value of employees in an organization because technology requires human resources to operate. With issues such as globalization, competition is becoming keener and keener in most industries. This situation also affects the job market in the sense that organization demand in human resources to remain competition in their respective industries is higher. To remain more competitive, organizations need therefore not to only attract the best talents but also to retain them on the job for a long term. The toughest challenge that organizations encounter nowadays is not only how to manage the 
people but also how to keep them on the job as long as possible and how to maintain them vigorous and ambitious. This study focuses on employee retention.

Employee retention is concerned with keeping or encouraging employees to remain in an organization for a maximum period of time [1]. Mita (2014) defined employee retention as "a technique adopted by businesses to maintain an effective workforce and at the same time meet operational requirements" [2]. Bidisha (2013) described it as "a process in which the employees are encouraged to remain with the organization for the maximum period of time or until the completion of the project" [1]. According to Workforce Planning for Wisconsin State Government (2015), employee retention is "a systematic effort to create and foster an environment that encourages employees to remain employed by having policies and practices in place that address their diverse needs" [3].

The objective of this literature review study is to analyze researches previous carried out in the field of employee retention to identify determining factors that are commonly identified by various researchers as the basis of their decision to stay in the organization.

In the course of this research which is descriptive in nature, secondary source has been used. The types of secondary data used are research journals and books. Many researchers approached employee retention using a group of individual factors such as employee motivation [4], job satisfaction [1], and organizational culture [5]. However, the study analyzed retention on the basis of individual factors basis.

\section{Determinants of Employee Retention}

\subsection{Overview}

Back in the 1990s, Fitz-enz (1990) observed that employee commitment and retention is not determined by a single issue but by a cluster of factors [6]. In previous researches a number of factors associated with employee retention have been identified. Factors that are commonly cited are developmental opportunities and quality supervision, job stress and colleague stress [7]; compensation and appreciation of work done, provision of challenging work, promotion and development chances, attractive atmosphere within the organization, relationships with colleagues, work-life balance, communication [8] and supervision [9].

According to Ghapanchi and Aurum (2011) retention factors include remuneration and benefits, training opportunities, fair and equal treatment, organizational culture [10]. While Allen and Shanock (2013) stressed on relationship with colleague socialization [11], Andrews and Wan (2009) emphasized on management style and leadership to increase an organization retention capability [12]. A group of researchers led by Loan-Clarke (2010) noted autonomy, work-schedule flexibility and social support help organization to keep their employees for a longer period of time [13]. Christeen (2014) identified eight retention factors: management, conducive environment, social support and development opportunities, autonomy, compensation, crafted workload, and work-life balance [14]. Our analysis of individual factors is mainly based on the work Christeen. In our opinion, the "crafted-sculpted workload" falls under management and leadership because it is the responsibility of management to allocate work according to the abilities of the job holder and few studies identified it as a determining factor. However, "training and development" was added on the basis of the papers we studied.

\subsection{Development Opportunities}

Professional development is not a least retention cause. Hiltrop (1999) related perceived careers success and organization ability to make employees stay in their jobs [15]. Personal and professional growth is a determining factor of retention and promotion opportunities increases employee commitment to stay [16]. Rolfe (2005) discovered a direct correlation between job resignation and issues related to career development [17]. Arnold (2005), Herman (2005) also observed direct relationship between development opportunities and retention [18] [19]. Prince (2005) also identified promotion and opportunities for growth as a significant reason for which employees decide to leave or stay in an organization and went further by identifying influential factors pertaining to career growth opportunities, which are: advancement plans, internal promotion and accurate career previews [20]. Retention is high where continued learning is not encouraged [21]. Daniels and his research colleagues asserted that promotion positively influences retention [22]. In organizations where the proper training is given to employees, retention rates are high [23]. Tymon and his co-researcher, and Pitts and his research team linked perceived career success and retention [24] [25]. Cardy and Lengnick-Hall (2011) on the one hand and Kroon 
and Freese (2013) on the other hand discovered that developmental opportunities can positively increase an employee's commitment to stay in an organization [26] [27].

\subsection{Compensation}

The relation between pay and retention has been the subject of many studies. Researchers are not unanimous about the impact of pay on retention. For some, satisfaction with pay strongly correlates with the employee decision to stay in the organization. For others, pay does not have a direct influence on retention. In 1997 Trevor and his research team established that rise in pay increases retention capabilities of organizations [28]. Davies, Taylor, Savery (2001) are of the same viewpoint and observed that organizations, particularly those in the accommodation industry in Western Australia, do not make use of salary and benefits policies to increase retention [29]. Lambert, Lynne and Barton also reached the same conclusion in a latter research they conducted [30]. Transparency of pay decisions have been cited as a booster of retention [16] [31]. Gardner, Van Dyne, and Pierce (2004) did not see pay as only a motivator but also a retention technique [32]. Hytter (2007) reached the conclusion that there is correlation between retention and reward [33]. Milkovich \& Newman (2004) were more specific. They viewed monetary pay among all kinds of compensation as the most relevant factor in maintain employee [34]. Performance related pay has been identified as retention facilitator [35]. In 2006, team of researchers led by Tremblay also observed that performance related-pay is a retention facilitator [36]. According to Hausknecht, Rodda and Howard (2009) extrinsic rewards (amount of pay and other benefits) are contributors of employee retention [37]. Pitts, Marvel and Fernandez (2011) observed that compensation is predictor of employee turnover [25]. Moncraz, Zhao and Kay (2009) were specific about the category of the workforce that reward affects most. They noted that pay reduces turnover and increases commitment among managers [23].

Shields \& Ward (2001), Gifford, Zammuto and Goodman (2002), and Hayes et al. (2006) noted that reward on its own does not constitute an important retention factor. Improved compensation can only increase retention capability in a short-term. For organizations to be more efficient in their attempt to make more employees stay in the organization for a long period improved compensation should be coupled with quality of work life which this group of researchers identified as a long-term factor [38]-[40]. Ellenbecker (2004) demonstrated that wage rates, especially among nurses, only have remote impact on retention [41].

\subsection{Work-Life Balance}

Work-life balance is becoming gradually more central for employees and tends to affect employees' decision to stay in organization. Nowadays employees long for flexible work schedules which allow them to take care of both their personal and professional life [41]. The balance between personal and professional lives is determined by the amount of sacrifice the individual is ready to make at the expense of other areas of life. Loan-Clarke, Arnold, Coombs, Hartley, and Bosley (2010) observed that a job that gives the holder the possibility to fulfill his/her family responsibilities increases employee retention [13]. Some employees first focus on the professional career and subsequently devote more time to other areas of their lives which was named the phenomenon of "downshifting" [42]. Kyndt, Dochy, Michielsen, and Moeyaert (2009) laid emphasis on the significance of a "healthy balance" [43]. As far as relationship between retention and work-life balance is concerned, Lener, Roehrs, and Piccone (2006) are of the view that employers should implement a "harmonious" balance to improve retention [44]. Osman (2013) found that offering emotional support to employees through work-life balance reduces their intention to quit their job [45]. Mita, Aarti \& Ravneeta (2014) observed a direct relation between employees' decision to stay and work-life balance [2].

\subsection{Management/Leadership}

Various studies noted that the way people are managed and the leadership style have direct influence on an organization ability to maintain its workforce. Eisenberger, Fasolo, Davis-LaMastro (1990) argued that the way employees view an organization is particularly dependent on their relationship with their supervisor [46]. Mc Neese-Smith (1995) found that the attitude of a hospital manager increase employee commitment to the organization [47]. The research of Kaye and Jordan-Evans (2002) laid emphasis on the fact a manager should be "a good boss” to impact retention positively [48]. Duffield and O’Brien-Pallas (2003) were more specific in the way leadership and retention correlate and viewed participative leadership style as a contributing factor of 
employee retention [49]. Kroon and Freese (2013) are also of the view that participative leadership style plays a significant role in employee retention [27]. Andrews and Wan (2009) were less specific about the particular style of leadership that positively impacts the capability of an organization to make its employees stay. However, they noted that management plays a determinant role in employee retention and established that there is a direct correlation between employee retention and manager behavior. The impact of management on employee retention can be viewed from two perspectives: leadership style and management support [14]. Involvement of employee in decision making motivates them to stay in an organization [36]. Noah (2008) observed that participation in decision-making process makes employees feel they are part of the organization and this increases loyalty and retention [50].

As far as support is concerned, Eisenberger, Stinglhamber, Vandenberghe, Sucharski and Rhoades (2002), and Paillé (2013) observed that management support is even more important than the organizational one [51] [52]. According to Ellett, Ellis, Westbrook and Dews (2007) "supportive, quality supervision" and "leadership that values employees" has a positive impact on retention [53]. Joo (2010) mentioned the fact of being supervised in a supportive manner is a contributor to retention [54]. Tymon, Stumpf, and Smith (2011) as well as Mignonac and Richebé (2013) identified supportive supervision from managers as a contributing factor to employee retention [24] [55]. Other researchers who observe the same relationship between perceived management support and retention [9] [16] [25] [56].

\subsection{Work Environment}

A conducive work environment appears to be an essential factor in employee retention. Spence, Leiter, Day, and Gilin (2009) gathered evidence supporting the fact that favorable working environment contributes to employee retention [57]. A conducive environment can be defined as a flexible atmosphere where working experience is enjoyable, resources are adequately provided. In their respective studies, Alexander, Lichtenstein, Oh and Ullman (1998) then Wood and his research team (2013) reached the conclusion that availability of resource can be a determinant factor in retention [58] [59]. For Ellett,Ellis, Westbrook and Dews (2007) and subsequently Loan-Clarke and his colleagues (2010), flexibility plays an important role, particularly in the retention of health workers [13] [53]. For workplace to be a conducive factor of retention it should be enjoyable [16]. The research of Moncarz and his co-researchers (2009) emphasized that the importance of a fun working environment and flexibility [23]. It appears that contributing factors of conducive working environment are flexibility, a fun workplace and availability of resources.

\subsection{Social Support}

Social support basically relates to the degree of satisfactory relationship with colleagues or fellow employees. Relationship with co-workers appears to be determinant factor of retention. Alexander and his research team (1998) and Tai, Bame and Robinson (1998) identified support from co-workers as a contributing factor of retention [58] [60]. Wells and Thelen (2002) established a direct correlation between good human resource practices and the ability to gain employees commit and to increase the chances of retaining them [61]. Miller, Erickson and Yust (2001) noted commitment can be gained by improving feeling of belongingness [62]. Jasper (2007) carried out a research that revealed that manager-employee relationship is the second most frequent reason why jobs are quit [63]. Satisfaction with relationship with colleagues or fellow employees was identified as retention factor [25]. Ramlall (2003) emphasized the fact that identifying and catering for employees' individual needs provides a favorable work environment that increases their commitment [64].

\subsection{Autonomy}

Autonomy "can be seen to be characterized by the ability to choose how to do one's work; having influence over one's work; and flexibility in workload decisions" [14]. Prior to the year 2000, Alexander, Lichtenstein, and Ullman (1998); Tai, Bame, and Robinson (1998); Boyle, Bott, Hansen, Woods, and Tauntan (1999) related employee retention to autonomy [58] [60] [65]. Subsequently Ellenbecker (2004); Hart (2005); Tremblay, O’BrienPallas, Viens, Brabant and Gelinas (2006) observed that autonomy on the job is a determinant factor of job satisfaction and thus to retention [36] [41] [66]. Kooker, Shoultz, and Codier (2007), Andrews and Wan (2009) identified autonomy as an influential factor of job retention [12] [67]. Spence, Leiter, Day and Gilin (2009) also 
observed that autonomy on the job influences employee decision to stay in the organization [57].

Ellenbecker (2004) established that there is job strain or lack or control over one's job contributes to job dissatisfaction which in turn impact negatively retention. Autonomy and control work activities leads to job satisfaction which positively influence retention [46]. Spence Leiter, Day and Gilin (2009) also linked autonomy and retention through job satisfaction. They observed that autonomy is predictor of job satisfaction [57].

\subsection{Training and Development}

Messmer (2000) viewed that a key factor to employee retention is training and development [68]. Deery (2008) observed that on the job training increases retention and commitment [69]. Leidner (2013) is also of the view that employee loyalty is improved through training and development [70].

\section{Conclusion}

The need for organizations to retain their talents is crucial for their ability to remain in business depends on it. Although this study attempted to bring forth all the factors related to employee retention, this complex area of human resource needs further investigations. Some factors such as organization culture, training and development, autonomy are less explored than supervision and leadership for instance. The workforce of an organization can be classified into three categories: directors, managers and employees. Existing researches did not lay enough emphasis on the category of employees, the sector of the economy and the type of businesses that are particularly affected by one factor or the other, though some studies did. For further investigations to better equip organizations with knowledge necessary to improve their retention capability are needed.

\section{References}

[1] Bidisha, L. D and Mukulesh, B. (2013) Employee Retention: A Review of Literature. Journal of Business and Management, 14, 8-16.

[2] Mita, M., Aarti K. and Ravneeta, D. (2014) Study on Employee Retention and Commitment. International Journal of Advance Research in Computer Science and Management Studies, 2, 154-164.

[3] Workforce Planning for Wisconsin State Government (2005) Employee Retention. http://workforceplanning.wi.gov/category.asp?linkcatid=15\&linkid=18

[4] Samuel, M.O. and Chipunza, C. (2009) Employee Retention and Turnover: Using Motivational Variables as a Panacea. African Journal of Business Management, 3, 410-415.

[5] Sheridan, J.E. (1992) Organizational Culture and Employee Retention. Academy of Management Journal, 35, 10361056. http://dx.doi.org/10.2307/256539

[6] Fitz-enz, J. (1990) Getting and Keeping Good Employees. In Personnel, 67, 25-29.

[7] Brown, L.K., Schultz, J.R., Forsberg, A.D., King, G., Kocik, S.M. and Butler, R.B. (2002) Predictors of Retention among HIV/Haemophilia Health Care Professionals. General Hospital Psychiatry, 24, 48-54. http://dx.doi.org/10.1016/S0163-8343(01)00172-4

[8] Walker, J.W. (2001) Zero Defections? Human Resource Planning, 24, 6-8.

[9] Naqvi, S.M.M.R. and Bashir, S. (2015) IT-Expert Retention through Organizational Commitment: A Study of Public Sector Information Technology Professionals in Pakistan. Applied Computing and Informatics, 11, 60-75. http://dx.doi.org/10.1016/j.aci.2011.11.001

[10] Ghapanchi, A.H. and Aurum, A. (2011) Antecedents to IT Personnel's Intentions to Leave: A Systematic Literature Review. Journal of Systems and Software, 84, 238-249. http://dx.doi.org/10.1016/j.jss.2010.09.022

[11] Allen, D.G. and Shanock, L.R. (2013) Perceived Organizational Support and Embeddedness as Key Mechanisms Connecting Socialization Tactics to Commitment and Turnover among New Employees. Journal of Organizational Behaviour, 34, 350-369. http://dx.doi.org/10.1002/job.1805

[12] Andrews, D.R. and Wan, T.T. (2009) The Importance of Mental Health to the Experience of Job Strain: An EvidenceGuided Approach to Improve Retention. Journal of Nursing Management, 17, 340-351. http://dx.doi.org/10.1111/j.1365-2934.2008.00852.x

[13] Loan-Clarke, J., Arnold, J., Coombs, C., Hartley, R. and Bosley, S. (2010) Retention, Turnover and Return-A Longitudinal Study of Allied Health Professionals in Britain. Human Resource Management Journal, 20, 391-406. http://dx.doi.org/10.1111/j.1748-8583.2010.00140.x 
[14] Christeen, G. (2015) Retaining Professional Workers: What Makes Them Stay? Employee Relations, 37, 102-121. http://dx.doi.org/10.1108/ER-10-2013-0151

[15] Hiltrop, J.M. (1999) The Quest for the Best: Human Resource Practices to Attract and Retain Talent. European Management Journal, 17, 422-430. http://dx.doi.org/10.1016/S0263-2373(99)00022-5

[16] Horwitz, F.M., Heng, C.T. and Quazi, H.A. (2003) Finders, Keepers? Attracting, Motivating and Retaining Knowledge Workers. Human Resource Management Journal, 13, 23-44. http://dx.doi.org/10.1111/j.1748-8583.2003.tb00103.x

[17] Rolfe, H. (2005) Building a Stable Workforce: Recruitment and Retention in the Child Care and Early Years Sector. Children and Society, 19, 54-65. http://dx.doi.org/10.1002/chi.829

[18] Arnold, E. (2005) Managing Human Resources to Improve Employee Retention. Health Care Manager, 24, 132-140. http://dx.doi.org/10.1097/00126450-200504000-00006

[19] Herman, R.E. (2005) HR Managers as Employee-Retention Specialists. Employment Relations Today, 32, 1-7. http://dx.doi.org/10.1002/ert.20058

[20] Prince, B.J. (2005) Career-Focused Employee Transfer Processes. Career Development International, 10, 293-309. http://dx.doi.org/10.1108/13620430510609136

[21] Stichler, J.F. (2005) Recruitment and Retention Strategies, Creating the Best Workplace for Women’s Services. AWHONN Lifelines, 9, 404-407. http://dx.doi.org/10.1177/1091592305283157

[22] Daniels, Z.M., VanLeit, B.J., Skipper, B.J., Sanders, M.L. and Rhyne, R.L. (2007) Factors in Recruiting and Retaining Health Professionals for Rural Practice. The Journal of Rural Health, 23, 62-71. http://dx.doi.org/10.1111/j.1748-0361.2006.00069.x

[23] Moncarz, E., Zhao, J. and Kay, C. (2009) An Exploratory Study of US Lodging Properties' Organizational Practices on Employee Turnover and Retention. International Journal of Contemporary Hospitality Management, 21, 437-458. http://dx.doi.org/10.1108/09596110910955695

[24] Tymon Jr., W.G., Stumpf, S.A. and Smith, R.R. (2011) Manager Support Predicts Turnover of Professionals in India. Career Development International, 16, 293-312. http://dx.doi.org/10.1108/13620431111140174

[25] Pitts, D., Marvel, J. and Fernandez, S. (2011) So Hard to Say Goodbye? Turnover Intention among US Federal Employees. Public Administration Review, 71, 751-760. http://dx.doi.org/10.1111/j.1540-6210.2011.02414.x

[26] Cardy, R.L. and Lengnick-Hall, M.L. (2011) Will They Stay or Will They Go? Exploring a Customer-Oriented Approach to Employee Retention. Journal of Business and Psychology, 26, 213-217. http://dx.doi.org/10.1007/s10869-011-9223-8

[27] Kroon, B. and Freese, C. (2013) Can HR Practices Retain Flexworkers with Their Agency? International Journal of Manpower, 34, 899-917. http://dx.doi.org/10.1108/IJM-07-2013-0169

[28] Trevor, C.O., Gerhart, B. and Boudreau, J.W. (1997) Voluntary Turnover and Job Performance: Curvilinear and the Moderating Influences of Salary Growth and Promotions. Journal of Applied. Psychology, 82, 44-61. http://dx.doi.org/10.1037/0021-9010.82.1.44

[29] Davies, D., Taylor, R. and Savery, C. (2001) The Role of Appraisal, Remuneration and Training in Improving Staff Relations in the Western Australian Accommodation Industry: A Comparative Study. Journal of European Industrial Training, 25, 366-373. http://dx.doi.org/10.1108/EUM0000000005837

[30] Lambert, E.G., Lynne Hogan, N. and Barton, S.M. (2001) The Impact of Job Satisfaction on Turnover Intent: A Test of a Structural Measurement Model Using a National Sample of Workers. The Social Science Journal, 38, 233-250. http://dx.doi.org/10.1016/S0362-3319(01)00110-0

[31] Baron, J.N, Hannan, M.T. and Burton, M.D. (2001) Labor Pains: Changes in Organizational Models and Employee Turnover in Young, High Tech Firms. American Journal of Sociology, 106, 960-1012. http://dx.doi.org/10.1086/320296

[32] Gardner, D.G., Van Dyne, L. and Pierce, J.L. (2004) The Effects of Pay Level on Organization-Based Self-Esteem and Performance: A Field Study. Journal of Occupational and Organizational Psychology, 77, 307-322. http://dx.doi.org/10.1348/0963179041752646

[33] Hytter, A. (2007) Retention Strategies in France and Sweden. Irish Journal of Management, 28, 59-79.

[34] Milkovich, G.M. and Newman, J.M. (2004) Compensation. 8th Edition, Irwin McGraw-Hill, Burr Ridge.

[35] Rambur, B., McIntosh, B., Palumbo, M.V. and Reinier, K. (2005) Education as a Determinant of Career Retention and Job Satisfaction among Registered Nurses. Journal of Nursing Scholarship, 37, 185-192. http://dx.doi.org/10.1111/j.1547-5069.2005.00031.x

[36] Tremblay, M.L., O’Brien-Pallas, L., Viens, C., Brabant, L.H. and Gelinas, C. (2006) Towards an Integrated Approach for the Management of Ageing Nurses. Journal of Nursing Management, 14, 207-212.

http://dx.doi.org/10.1111/j.1365-2934.2006.00604.x 
[37] Hausknecht, J.P., Rodda, J. and Howard, M.J. (2009) Targeted Employee Retention: Performance Based and Job-Related Differences in Reported Reasons for Staying. Human Resource Management, 48, 269-288. http://dx.doi.org/10.1002/hrm.20279

[38] Shields, M.A. and Ward, M. (2001) Improving Nurse Retention in the National Health Service in England: The Impact of Job Satisfaction on Intentions to Quit. Journal of Health Economics, 20, 677-701. http://dx.doi.org/10.1016/S0167-6296(01)00092-3

[39] Gifford, B.D., Zammuto, R.F. and Goodman, E.A. (2002) The Relationship between Hospital Unit Culture and Nurses' Quality of Work Life. Journal of Healthcare Management, 47, 13-25.

[40] Hayes, L.J., O’Brien-Pallas, L., Duffield, C., Shamian, J., Buchan, J., Hughes, F., Laschinger, H.K.S., North, N. and Stone, P.W. (2006) Nurse Turnover: A Literature Review. International Journal of Nursing Studies, 43, 237-263. http://dx.doi.org/10.1016/j.ijnurstu.2005.02.007

[41] Ellenbecker, C.H. (2004) A Theoretical Model of Job Retention for Home Health Care Nurses. Journal of Advanced Nursing, 47, 303-310. http://dx.doi.org/10.1111/j.1365-2648.2004.03094.x

[42] Laabs, J.J. (1996) Downshifters. Personnel Journal, 75, 62-70.

[43] Kyndt, E., Dochy, F., Michielsen, M. and Moeyaert, B. (2009) Employee Retention: Organizational and Personal Perspectives. Vocations and Learning, 2, 195-215. http://dx.doi.org/10.1007/s12186-009-9024-7

[44] Leners, D., Roehrs, C. and Piccone, A. (2006) Tracking the Development of Professional Values in Undergraduate Nursing Students. Journal of Nursing Education, 45, 504-511.

[45] Osman, M.K. (2013) High-Performance Work Practices and Hotel Employee Performance: The Mediation of Work Engagement. International Journal of Hospitality Management, 32, 132-140. http://dx.doi.org/10.1016/j.ijhm.2012.05.003

[46] Eisenberger, R., Fasolo, P. and Davis-LaMastro, V. (1990) Perceived Organizational Support and Employee Diligence, Commitment, and Innovation. Journal of Applied Psychology, 75, 51-59. http://dx.doi.org/10.1037/0021-9010.75.1.51

[47] McNeese-Smith D., (1995) Job Satisfaction, Productivity, and Organizational Commitment. Journal of Nurse Association, 25, 17-26. http://dx.doi.org/10.1097/00005110-199509000-00006

[48] Kaye, B. and Jordan-Evans, S. (2002) Retention in Tough Times: Here's What 25 Global Talent Leaders Say about Keeping Good People-Especially Now. Talent Development, 56, 32-37.

[49] Duffield, C. and O’Brien-Pallas, L. (2003) The Causes and Consequences of Nursing Shortages: A Helicopter View of the Research. Australian Health Review, 26, 186-193. http://dx.doi.org/10.1071/AH030186

[50] Noah, Y. (2008) A Study of Worker Participation in Management Decision Making within Selected Establishments in Lagos, Nigeria. Journal of Social Science, 17, 31-39.

[51] Eisenberger, R., Stinglhamber, F., Vandenberghe, C., Sucharski, I.L. and Rhoades, L. (2002) Perceived Supervisor Support: Contributions to Perceived Organizational Support and Employee Retention. Journal of Applied Psychology, 87, 565-573. http://dx.doi.org/10.1037/0021-9010.87.3.565

[52] Paillé, P. (2013) Organizational Citizenship Behaviour and Employee Retention: How Important Are Turnover Cognitions? The International Journal of Human Resource Management, 24, 768-790. http://dx.doi.org/10.1080/09585192.2012.697477

[53] Ellett, A.J., Ellis, J.I., Westbrook, T.M. and Dews, D. (2007) A Qualitative Study of 369 Child Welfare Professionals’ Perspectives about Factors Contributing to Employee Retention and Turnover. Children and Youth Services Review, 29, 264-281. http://dx.doi.org/10.1016/j.childyouth.2006.07.005

[54] Joo, B.K.B. (2010) Organizational Commitment for Knowledge Workers: The Roles of Perceived Organizational Learning Culture, Leader-Member Exchange Quality, and Turnover Intention. Human Resource Development Quarterly, 21, 69-85. http://dx.doi.org/10.1002/hrdq.20031

[55] Mignonac, K. and Richebé, N. (2013) “No Strings Attached?”: How Attribution of Disinterested Support Affects Employee Retention. Human Resource Management Journal, 23, 72-90. http://dx.doi.org/10.1111/j.1748-8583.2012.00195.x

[56] Karatepe, O.M. (2013) High-Performance Work Practices, Work Social Support and Their Effects on Job Embeddedness and Turnover Intentions. International Journal of Contemporary Hospitality Management, 25, 903-921. http://dx.doi.org/10.1108/IJCHM-06-2012-0097

[57] Spence Laschinger, H.K., Leiter, M., Day, A. and Gilin, D. (2009) Workplace Empowerment, Incivility, and Burnout: Impact on Staff Nurse Recruitment and Retention Outcomes. Journal of Nursing Management, 17, 302-311. http://dx.doi.org/10.1111/j.1365-2834.2009.00999.x

[58] Alexander, J.A., Lichtenstein, R., Oh, H.J. and Ullman, E. (1998) A Causal Model of Voluntary Turnover among Nursing Personnel in Long-Term Psychiatric Settings. Research in Nursing and Health, 21, 415-427.

http://dx.doi.org/10.1002/(SICI)1098-240X(199810)21:5<415::AID-NUR5>3.0.CO;2-Q 
[59] Wood, M.E., Mansoor, G.F., Hashemy, P., Namey, E., Gohar, F., Ayoubi, S.F. and Todd, C.S. (2013) Factors Influencing the Retention of Midwives in the Public Sector in Afghanistan: A Qualitative Assessment of Midwives in Eight Provinces. Midwifery, 29, 1137-1144. http://dx.doi.org/10.1016/j.midw.2013.07.004

[60] Tai, T.W., Bame, S.I. and Robinson, C.D. (1998) Review of Nursing Turnover Research, 1977-1996. Social Science and Medicine, 47, 1905-1924. http://dx.doi.org/10.1016/S0277-9536(98)00333-5

[61] Wells, M. and Thelen, L. (2002) What Does Your Workspace Say about You? The Influence of Personality, Status and Workspace on Personalization. Environment and Behavior, 34, 300-321. http://dx.doi.org/10.1177/0013916502034003002

[62] Miller, N., Erickson, A. and Yust, B. (2001) Sense of Place in the Workplace: The Relationship between Personal Objects and Job Satisfaction and Motivation. Journal of Interior Design, 27, 35-44. http://dx.doi.org/10.1111/j.1939-1668.2001.tb00364.x

[63] Jasper, M. (2007) The Significance of the Working Environment to Nurses’ Job Satisfaction and Retention. Journal of Nursing Management, 15, 245-247. http://dx.doi.org/10.1111/j.1365-2834.2007.00760.x

[64] Ramlall, S. (2003) Managing Employee Retention as a Strategy for Increasing Organizational Competitiveness. Applied H.R.M. Research, 8, 63-72.

[65] Boyle, D.K., Bott, M.J., Hansen, H.E., Woods, C.Q. and Tauntan, R.L. (1999) Managers’ Leadership and Critical Care Nurses’ Intent to Stay. American Journal of Critical Care, 8, 361-371.

[66] Hart, S.E. (2005) Hospital Ethical Climates and Registered Nurses’ Turnover Intentions. Journal of Nursing Scholarship, 37, 173-177. http://dx.doi.org/10.1111/j.1547-5069.2005.00030.x

[67] Kooker, B.M., Shoultz, J. and Codier, E.E. (2007) Identifying Emotional Intelligence in Professional Nursing Practice. Journal of Professional Nursing, 23, 30-36. http://dx.doi.org/10.1016/j.profnurs.2006.12.004

[68] Messmer, M. (2000) Orientations Programs Can Be Key to Employee Retention. Strategic Finance, 81, 12-15.

[69] Deery, M., (2008) Talent Management, Work-Life Balance and Retention Strategies. International Journal of Contemporary Hospitality Management, 20, 792-806. http://dx.doi.org/10.1108/09596110810897619

[70] Leidner, S. and Simon, M.S. (2013) Keeping Potential Job-Hoppers' Feet on Ground. Human Resource Management International Digest, 21, 31-33. http://dx.doi.org/10.1108/09670731311296492 